\title{
Improved method to determine particle size distribution for some gypsiferous soils. A case study from Al-Ahsa Governorate, Saudi Arabia
}

\author{
Magboul Sulieman a,b,*, Abd El-Azeem Sallam a \\ a Department of Soil Sciences, College of Agriculture, King Saud University, Riyadh, Saudi Arabia \\ ${ }^{b}$ Department of Soil and Environment Sciences, Faculty of Agriculture, University of Khartoum, Khartoum North,
} Shambat, Sudan

\section{Article Info}

Received : 03.03.2016

Accepted : 05.05.2016

\begin{abstract}
Until now, there is no method can be used to accurately assess the particles size distribution as well as textural classes of gypsiferous soils for proper interpretation of physical behavior of these soils, and most laboratory methods involve pretreatment to remove gypsum from the samples. Therefore, the results of the particle size distribution do not reflect the size distribution of the whole soil. This study aimed to develop an alternative method to determine particle size distribution for some gypsiferous soils selected from Al-Ahsa governorate, Saudi Arabia. Five samples from different profiles with different gypsum content were selected to evaluate the modified method. Sand fractions were separated with three disaggregation methods: 1) drying sieving, 2) shaking for 5 hours in a 7:3 ethanol: water solution, and 3) sonication for 3 minutes in a 7:3 ethanol: water solution. The statistical analysis results revealed that the sonication for 3 minutes in a 7:3 ethanol: water solution was the most effective method for separating sand fractions as compared to dry sieving and shaking. Meanwhile, there was slight difference in separating sand fractions between sonication for 3 minutes and shaking for 5 hours. The particle size distribution by the developed method showed increasing in total sand content as compared to standard particle size method. Likewise, comparison of the CEC/clay ratio between the two methods also indicated that the developed method yielded clay contents more consistent with other property data for the same horizons. Consequently, the textural classes obtained from the two methods were different. Therefore; we concluded that the determination of particle size distribution for gypsiferous soils ( $\leq 40 \%$ gypsum) using this developed method will improve the understanding and ability to proper interpret of physical behavior of these unique soils. We highly recommended using this developed method to separate soil particles from the gypsiferous soils.
\end{abstract}

Keywords: Gypsiferous soils, Al-Ahsa governorate, disaggregation methods, sonication.

(C) 2016 Federation of Eurasian Soil Science Societies. All rights reserved

\section{Introduction}

Gypsiferous soils (1 to 40\% gypsum) are widely scattered throughout the Kingdom of Saudi Arabia and are particularly extensive in the Eastern Region from the Kuwait/Iraq border South to the sands of the Empty Quarter. The general characteristics of these soils they are; located on plains, shallow to moderately deep with loamy texture, highly saline and are mostly unsuitable for agricultural purposes (Vincent, 2008).

According to the World Reference Base for Soil Resources (FAO, 1990), the gypsiferous soils in Saudi Arabia cover about $82.5 \mathrm{~km}^{2}$ (approximately $0.04 \%$ of the total area). In contrast; the general soil map of the

\footnotetext{
${ }^{*}$ Corresponding author.

Department of Soil Sciences, College of Agriculture, King Saud University, 2640, Riyadh, Saudi Arabia

Tel.: +966542995460

E-mail address: magboul@uofk.edu e-ISSN: 2147-4249 DOI: 10.18393/ejss.2016.4.322-331
} 
Kingdom of Saudi Arabia (Soil Atlas, 1984) estimated that the gypsiferous soils in Saudi Arabia cover around $1622.66 \mathrm{~km}^{2}$ (approximately $8.5 \%$ of total area). The reason for this significant variation is that the world map for gypsiferous soils distribution shows only area of Yermosols and Xerosols which have a gypsic or petrogypsic subsurface horizon, and the other soils which may have a gypsic horizon (e.g; Calcic units of Yermosols, Xerosols, Chernozems and Calcic Cambisols and Solonchaks) are not taken into account.

The estimation of soil texture of the gypsiferous soils under field conditions is misleading due to the presence of gypsum crystals in various sand-sized fractions. Consequently, the forms and degree of crystallization of gypsum particles influence the feel of the soil and as a result, field estimates of texture are generally coarser than indicated by laboratory methods (Soil Survey Staff, 2014b).

Until now, there is no method can be used to accurately assess the particles size distribution as well as textural classes of gypsiferous soils for proper interpretation of physical behavior of these soils (Pearson et al. 2014). However, most laboratory methods for determining particle size distribution of gypsiferous soils involve pretreatment to remove gypsum and more soluble salts as well as iron oxides (Soil Survey Staff, 2014b). Consequently, the particle size measurements by these methods indicate the size distribution of essentially insoluble, dominantly silicate minerals, and do not indicate the size distribution of the whole soil including gypsum (Porta, 1998).

Pearson et al. (2014) proposed an alternative method to determine particle size distribution in gypseous soils ( $\geq 40 \%$ gypsum content). The method consists of two independent measures of particle size; 1 ) the amount and distribution of sand-sized particles including gypsum particles, and 2) clay content of a whole soil (including gypsum) basis using the measured gypsum content of the sample.

In this study, we further develop the Pearson et al. (2014) method to determine the particle size distribution in some gypsiferous soils ( $\leq 40 \%$ gypsum content) selected from Al-Ahsa governorate, Saudi Arabia.

This study tried to address the following questions: (1) which disaggregation methods are most suitable to separate sand fractions for gypsiferous soils? (2) Are there significant differences in particle size distribution as well as textural class obtained by standard method and the developed method for gypsiferous soils? (3) Is this modified method suitable to determine particle size distribution for gypsiferous soils?

\section{Material and Methods}

\section{Site description}

The study area is located in the eastern part of Al-Ahsa governorate, Saudi Arabia (Figure 1). The study area falls within the arid climatic zone. The average annual rainfall varies from 0 to $<100 \mathrm{~mm}$. The monthly mean maximum temperature of the hottest months (June and July) is $38^{\circ} \mathrm{C}$. Monthly mean minimum temperature of the coldest month (January) is less than $25^{\circ} \mathrm{C}$. The monthly mean relative humidity ranges between 40 to $60 \%$ (April to August) and > 60\% (January to March) and (September to December). All sampling locations were covered with natural vegetation especially Haloxylon sallicornicum and some area were cultivated with old date palms.

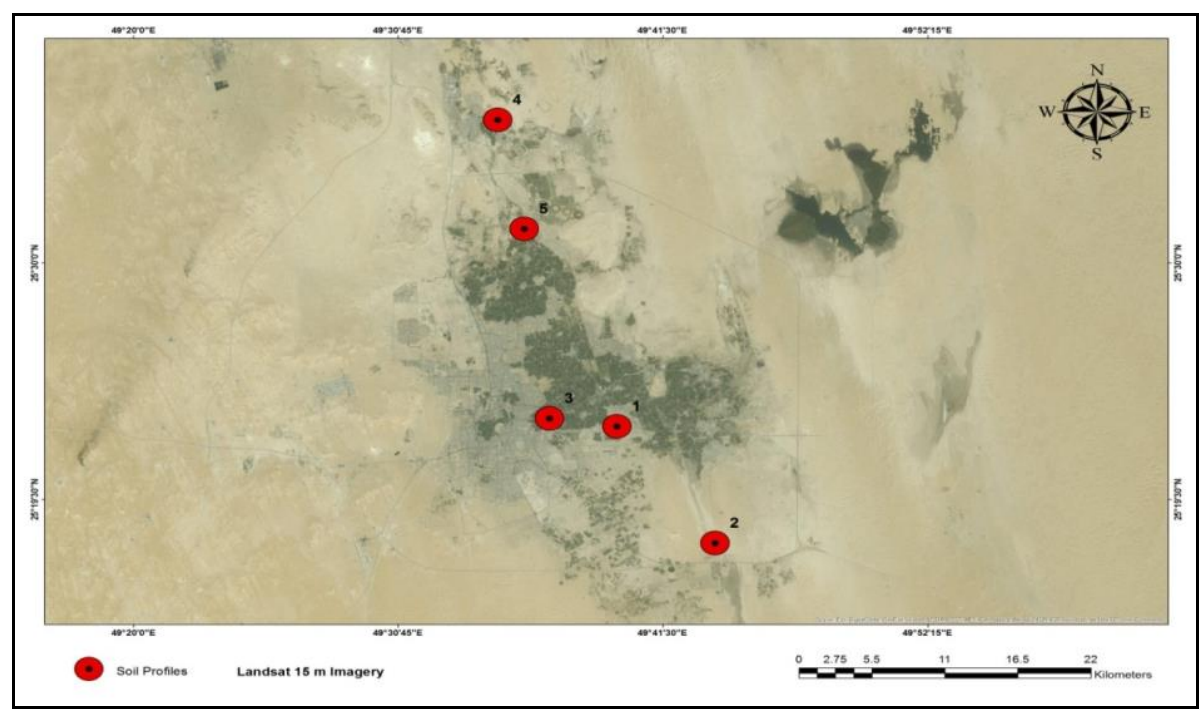

Figure 1. Location of the study area and samples sites 
Table 1 presents the geographical coordinates of the sampling sites. The calculated soil temperature regime is hyperthermic and soil moisture regime is aridic. Soil samples were collected from 5 representative profiles. All soil profiles were fully described (Appendix 1) according to the FAO Guideline for Soil profile Description (FAO, 2006). According to the USDA soil taxonomy (Soil Survey Staff, 2014a), the soils of the study area belong within Aridisols and classified as gypsids suborder.

Table 1. Geographical coordinates of the sampling sites within the study area.

\begin{tabular}{|c|c|c|c|c|}
\hline \multirow{2}{*}{ Profile No. } & \multirow{2}{*}{ Horizon } & \multicolumn{2}{|c|}{ Coordinates } & \multirow{2}{*}{$\begin{array}{c}\text { Classification } \\
\left.\text { (USDA }^{*}, 2014\right)\end{array}$} \\
\hline & & $\mathrm{N}$ & $E$ & \\
\hline Profile 1 & Czy $(5-25 \mathrm{~cm})$ & $25 \div 36 ' 51 "$ & 4932'54" & Typic Haplogypsids \\
\hline Profile 2 & Cky $(5-20$ cm) & $25 \div 30 ' 32 "$ & 493' $37^{\prime \prime}$ & Typic Calcigypsids \\
\hline Profile 3 & Czy $(25-45 \mathrm{~cm})$ & $25^{\circ} 17^{\prime} 00^{\prime \prime}$ & 49누' $16^{\prime \prime}$ & Typic Haplogypsids \\
\hline Profile 4 & Cky $(20-80 \mathrm{~cm})$ & $25 \div 17^{\prime} 00^{\prime \prime}$ & 494'12" & Typic Calcigypsids \\
\hline Profile 5 & Cky $(5-35 \mathrm{~cm})$ & $25 \div 31^{\prime} 30^{\prime \prime}$ & $49^{\circ} 35^{\prime} 52^{\prime \prime}$ & Typic Calcigypsids \\
\hline
\end{tabular}

${ }^{*}$ United State Department of Agriculture (Soil Survey Staff, 2014a,b)

\section{Soil sampling and analysis}

Five soil samples with different gypsum content were collected randomly from 5 profiles; profiles 1 and 2 were classified as Typic Haplogypsids; whereas, profiles 3, 4 and 5 were classified as Typic Calcigypsids. Selected physical and chemical properties of the samples used for the evaluation of the disaggregation methods are given in Table 2.

Table 2. Selected physical and chemical properties of the studied soil samples

\begin{tabular}{|c|c|c|c|c|c|c|c|c|c|c|c|c|}
\hline \multirow{2}{*}{$\begin{array}{c}\text { Profile } \\
\text { No. }\end{array}$} & \multirow{2}{*}{$\begin{array}{l}\text { Depth } \\
\text { (cm) }\end{array}$} & \multirow{2}{*}{$\begin{array}{l}\text { Gypsum } \\
\mathrm{g} \mathrm{kg}^{-1}\end{array}$} & \multirow[t]{2}{*}{$\mathrm{pH}^{\mathrm{a}}$} & \multirow{2}{*}{$\begin{array}{c}\mathrm{EC}^{\mathrm{b}} \\
\mathrm{dS} \mathrm{m}^{-1}\end{array}$} & \multirow{2}{*}{$\begin{array}{c}\text { CEC } \\
\text { cmol( }(+) k g^{-1}\end{array}$} & \multirow{2}{*}{$\begin{array}{c}\mathrm{BD} \\
\mathrm{kg} \mathrm{m}^{-3}\end{array}$} & \multirow{2}{*}{$\begin{array}{l}\mathrm{CaCO}_{3} \\
\mathrm{~g} \mathrm{~kg}^{-1}\end{array}$} & \multirow{2}{*}{$\begin{array}{c}\text { Field } \\
\text { texturec }\end{array}$} & \multicolumn{3}{|c|}{ Particle size distribution (\%) } & \multirow{2}{*}{$\begin{array}{l}\text { Textural } \\
\text { class }^{\mathrm{d}}\end{array}$} \\
\hline & & & & & & & & & Sand & Silt & Clay & \\
\hline P 1 & $5-25$ & 8 & 7.75 & 60.5 & 1.80 & 1.7 & 151 & $S$ & 74 & 0.4 & 25.2 & SCL \\
\hline P 2 & $5-20$ & 108.0 & 8.5 & 70.2 & 5.20 & 1. & 46 & SCL & 84 & 1.5 & 14.3 & LS \\
\hline P 3 & $0-25$ & 82.0 & 7.72 & 2.65 & 8.25 & 1.7 & 262 & SCL & 72.8 & 4.4 & 22.8 & SCL \\
\hline P 4 & $20-80$ & 53.0 & 7.78 & 4.45 & 7.60 & 1.8 & 70.2 & SCL & 89.6 & 3.7 & 6.8 & S \\
\hline P 5 & $5-35$ & 42.0 & 7.67 & 9.50 & 3.40 & 1.9 & 642 & SL & 84.0 & 8.5 & 7.5 & LS \\
\hline
\end{tabular}

a $\mathrm{pH}$ measured in 1:5 soil: water.

b Electrical conductivity of saturated paste extract.

cd scl: sandy clay loam, sl: sandy loam; s: sand; ls: loamy sand

Texture class by feel was evaluated in the field for different horizons and compared to those obtained by using USDA textural triangle (Soil Survey Staff, 2014b). In laboratory, samples were air-dried $\left(20-22^{\circ} \mathrm{C}\right)$ and passed through a $2 \mathrm{~mm}$ mesh sieve to obtain the fine soil fraction. The bulk density (BD) was determined in the field by using core method according to (Grossman and Reinsch, 2002). Particle size distribution was determined by using standard pipet method according to (Gee and Bauder, 1994). Soil chemical properties were determined according to the standard method (Sparks et al. 1996). Soil pH was measured potentiometrically in 1:5 soil/water suspension. Electrical conductivity (EC) was measured potentiometrically on a saturated paste extract. Gypsum percentage was evaluated by dissolution in water, precipitation in acetone, re-dissolution, and conversion of solution EC to percent gypsum. Cation exchange capacity (CEC) was determined using continuous leaching of $4 \mathrm{~g}$ of soil with $100 \mathrm{ml}$ of $1 \mathrm{M} \mathrm{NH}_{4} \mathrm{OAc}$ at pH 7 (4 g of air dry soil sample was treated three times with $1 \mathrm{M} \mathrm{NaOAc}$, washed three times with ethanol (95\%), and then extracted three times with $1 \mathrm{M} \mathrm{NH}_{4} \mathrm{OAc}$ ), and concentration of the exchangeable $\mathrm{Na}^{+}$was determined using flame photometer (model Corning 400), and then the CEC was calcluated using the equation described by (Sparks et al. 1996). Percent calcium carbonate $\left(\% \mathrm{CaCO}_{3}\right)$ was determined by calcimeter. The samples were treated with $0.1 \mathrm{~N} \mathrm{HCL}$; the volume of $\mathrm{CO}_{2}$ from pure calcium carbonate and samples were recorded, and the $\% \mathrm{CaCO}_{3}$ was then calculated according to Horváth et al. (2005).

\section{Separation of sand fractions by the developed method}

We used an alternative method described by Pearson et al. (2014) to separate sand fractions for five gypsiferous samples with gypsum content ranging from 4.2 to 10.8\%. Sand fractions were separated using three disaggregation methods with fundamental changes including increasing the specimen weight and minimizing the time of the separation. Main reason for minimizing the time is that gypsum in most gypsiferous soils is present as fine sand fraction $(125-25 \mu \mathrm{m})$, which may be greatly affected by great energy input via sonication or shaking. As a result the fine sand may pass via sieve as silt fraction which causes a 
decrease in total sand content and an increase in silt content. The three disaggregation methods are as follows: (1) Dry sieving- $25 \mathrm{~g}$ of air dried soil sample was sieved through a set of $53 \mu \mathrm{m}$ diameter sieves (1.0, $0.5,0.25,0.125$, and $0.053 \mathrm{~mm}$ openings) on a mechanical shaker for 3 minutes (shaking model HAVER EML 200 digital, Germany) and the fraction retained on each sieve was weighed. This method did not include addition of any chemical solutions to disperse samples; thus, it can be used to compare their obtained results with the other two methods for separating sand fractions from gypsiferous soils. (2) Shaking for 5 hours in a 7:3 ethanol: water solution- $25 \mathrm{~g}$ of soil suspended in a 7:3 ethanol: water solution and shaken for 5 hours on a reciprocating shaker Model (SSL1, orbital shaker). The suspension was then passed through a $53 \mu \mathrm{m}$-sieve, and sand fraction on each sieve weighted (wet weight), and left overnight to oven dry at $60^{\circ} \mathrm{C}$ (in order to avoid the change in gypsum contents as well as clay minerals, and which may occur if the samples have been dried at $105^{\circ} \mathrm{C}$ ) and then each fraction weighed for a second time (dry weight). (3) Sonication in a 7:3 ethanol: water solution- $25 \mathrm{~g}$ of soil was suspended in $50 \mathrm{ml}$ of a 7:3 ethanol: water solution and allowed to sit for 2 minutes in a $150 \mathrm{~mm}$ diameter beaker. Ultrasound energy was applied for 3 minutes via a sonicator Model (Sonics \& Materials Vibra-Cell VC600a, 600-Watt at $20 \mathrm{kHz}$ with $20 \mathrm{~mm}$ horn). The suspension was then passed through a $53 \mu \mathrm{m}$ - sieve, and sand fraction on each sieve weighted (wet weight), and left overnight to oven dry at $60^{\circ} \mathrm{C}$ and then each fraction weighed for a second time (dry weight). Individual sand separates in the three methods were calculated as a percentage of the whole soil sample. Total sand was calculated as the sum of the sand separates.

\section{Whole clay content measurement}

The clay content was measured after gypsum removal by the standard pipet method, and then re-calculated to a whole soil (including gypsum) using the following equation described by Pearson et al. (2014):

$$
\frac{\mathrm{g} \text { clay }}{\mathrm{g}<2 \mathrm{~mm} \text { soil }}=\frac{\mathrm{g} \text { non gypsum separate }}{\mathrm{g}<2 \mathrm{~mm} \text { soil }} \times \frac{\mathrm{g} \text { clay }}{\mathrm{g} \text { non gypsum separate }}
$$

Where; (g clay/g $<2 \mathrm{~mm}$ soil) is the calculated value of whole-soil clay content, (g non-gypsum separate/g $<2$ $\mathrm{mm}$ ) soil is the content of non-gypsum residue in the sample expressed as a decimal ([100-\% gypsum]/100), and (g clay/g non-gypsum separate) is the clay content of the non-gypsum residue.

\section{Whole soil silt measurement}

Whole soil silt percentage was calculated by subtracting the sand and clay percentages from 100 .

\section{Statistical analysis}

The influence of the three disaggregation methods on the sand fractions as well as total sand were statistically analyzed by a one way analysis of variance with Tukey significant difference test for mean separation $(\mathrm{P}<0.05)$. All statistical analysis was performed using SPSS software version 21.0 (IBM Corp., 2012).

\section{Results and Discussion}

\section{Selected physico-chemical soil properties}

Selected physico-chemical properties of the studied samples are presented in Table 2. Field texture ranged from sand to sandy clay loam. Bulk density was high and ranged from 1.7 to $1.9 \mathrm{~kg} \mathrm{~m}^{-3}$. The soil reaction was alkaline in all samples due to the presence of $\mathrm{CaCO}_{3}$ and the $\mathrm{pH}$ values ranged from 7.67 to 8.50. These results are similar to those others obtained with gypsisols (Artieda, 1996; Florea and Al-Joumaa, 1998; Cantón et al. 2003). All horizons showed salinity level and the electrical conductivity (EC) values ranged from 2.65 to $60.5 \mathrm{dS} \mathrm{m}^{-1}$. The $\mathrm{CaCO}_{3}$ content ranged from 46.0 to $642 \mathrm{~g} \mathrm{~kg}^{-1}$. Gypsum content varied in all samples and the values ranged from 42 to $108 \mathrm{~g} \mathrm{~kg}^{-1}$. The cation exchange capacity (CEC) ranged from 1.80

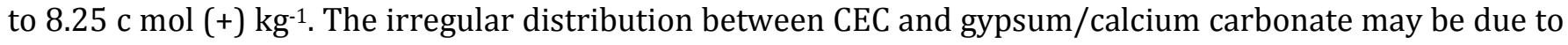
the presence of different clay minerals derived from different parent materials in the study area. Recently, it has been reported that the irregular distribution of $\mathrm{CEC}$ and $\mathrm{CaSO}_{4}$ or $\mathrm{CaCO}_{3}$ may be associated with different clay minerals (Aznar et al. 2013).

\section{Sand fractions separated by the three disaggregation methods}

Figures 2 to 5 shows the sand fractions of the studied soil samples with the three disaggregation treatments. In the three soil samples from profile $1(\mathrm{Czy}, 5-25 \mathrm{~cm})$, profile $2(\mathrm{Czy}, 0-25 \mathrm{~cm})$ and profile $3(\mathrm{Cky}, 20-80 \mathrm{~cm})$, the amount of very coarse sand decreased from dry sieving to shaking in a 7:3 ethanol: water solution to sonication in a 7:3 ethanol: water solution (Figure 2,3,4), respectively. This could be due to more complete 
disaggregation of the sample or fracture of primary grains if the energy input was too great. These results agreed with Pearson et al. (2014). In addition, the reduction in the amount of very coarse and coarse sand fractions has been reported in other studies of disaggregation treatments (Fuller and Goh, 1992; Imeson and Vis, 1984; Oades and Waters, 1991). In contrast, in soil samples from profile 4 (Cky, 20-80 cm), and from profile 5 (Cky, $5-35 \mathrm{~cm}$ ), the trend was from shaking in a 7:3 ethanol solution to a dry sieving to sonication in a 7:3 ethanol: water solution (Figure 5 and 6), respectively. The reason for this trend is unknown but might be due to the presence of gypsum crystals with fine sand-sized fractions which has not been influenced by the great energy input of sonication. These findings coincide with those reported by previous authors (AlBarrak and Rowell, 2006; Aznar et al. 2013; Poch et al. 2010). In contrast; the trends of the three disaggregation treatments for coarse sand, medium sand, fine sand and very fine sand was irregular among the soil samples. Reasons for this deviation from the trend is unknown but may be related to differences in parent materials. These results were similar to that obtained by Pearson et al. (2014).

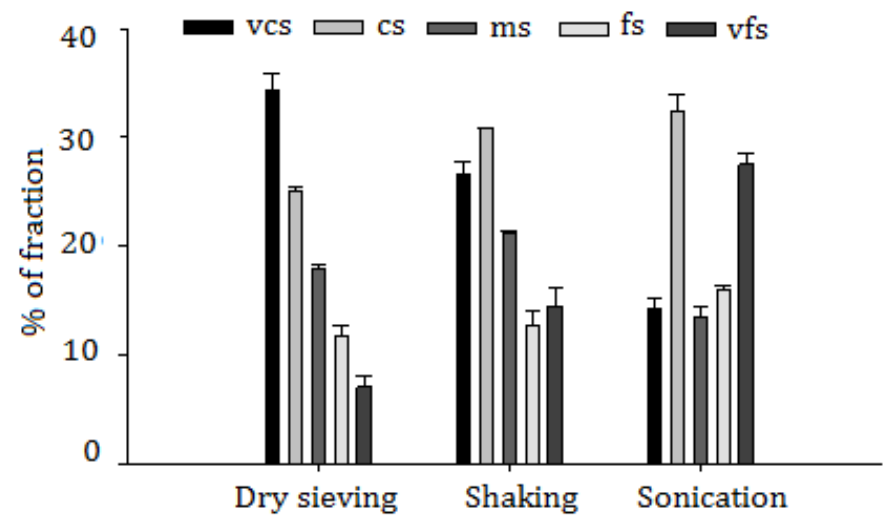

Figure 2. Sand fraction distribution after applying disaggregation methods in horizon Czy (5-25 cm) from profile 1 . Shaking $-15 \mathrm{hr}$ shaking in 7:3 ethanol: water solution; sonication- sonication for $3 \mathrm{~min}$. in 7:3 ethanol: water solution.

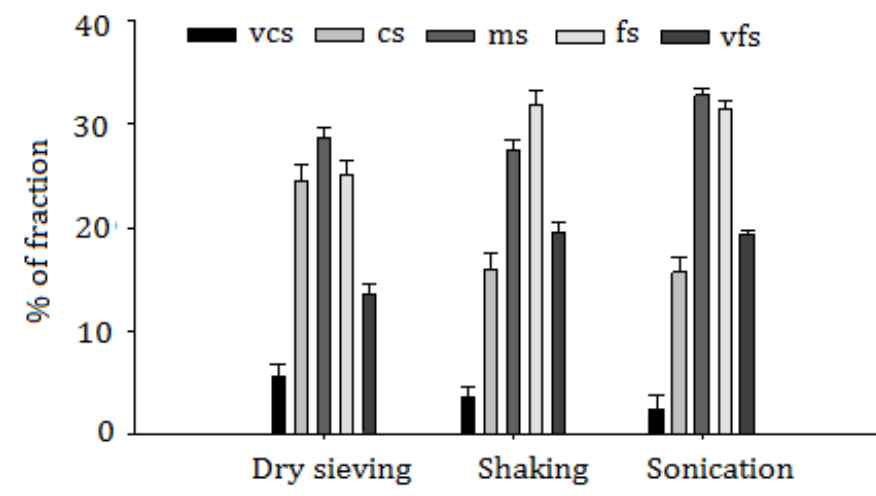

Figure 3. Sand fraction distribution after applying disaggregation methods in horizon Cky $(5-20 \mathrm{~cm})$ from profile 2 . Shaking $-15 \mathrm{hr}$ shaking in 7:3 ethanol solution; sonication- sonication for $3 \mathrm{~min}$. in 7:3 ethanol: water solution.

\section{Total sand by the three disaggregation methods}

Table 3 presents data for the amount of total sand measured with the three disaggregation methods. The table showed that the amount of total sand in profile 3 (Czy, 0-25 cm), profile 4 (Cky, 20-80 cm), and profile 5 (Cky, 5-35 cm) decreased from dry sieving to shaking in a 7:3 ethanol: water solution to sonication in a 7:3 ethanol: water solution. This might be due to more complete disaggregation of the sample or fracture of primary grains if the energy input was too great.

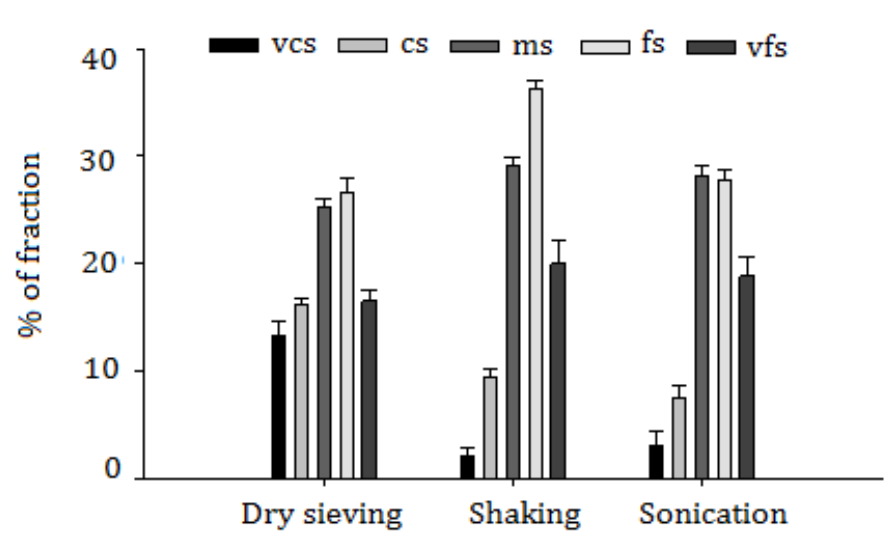

Figure 4. Sand fraction distribution after applying disaggregation methods in horizon Czy $(5-25 \mathrm{~cm})$ from profile 3. Shaking -15 hr shaking in 7:3 ethanol: water solution; sonication- sonication for $3 \mathrm{~min}$. in 7:3 ethanol: water solution.

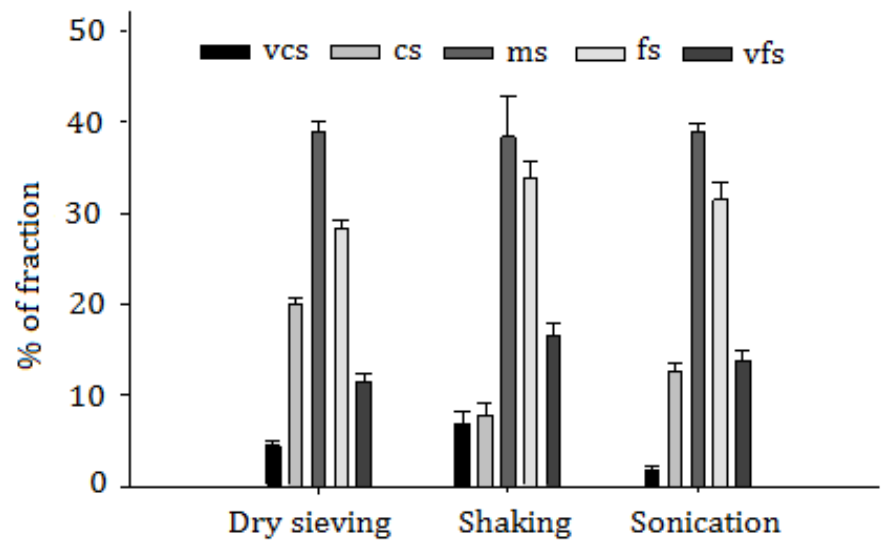

Figure 5. Sand fraction distribution after applying disaggregation methods in horizon Cky (20-80 cm) from profile 4 . Shaking $-15 \mathrm{hr}$ shaking in 7:3 ethanol: water solution; sonication- sonication for $3 \mathrm{~min}$. in 7:3 ethanol: water solution. 


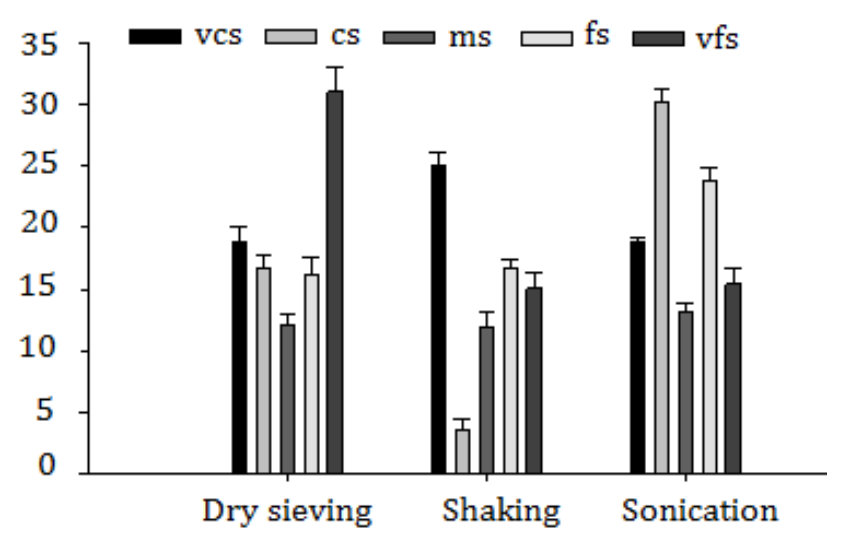

Figure 6. Sand fraction distribution after applying disaggregation methods in horizon Cky $(5-35 \mathrm{~cm})$ from profile 5. Shaking $-15 \mathrm{hr}$ shaking in 7:3 ethanol: water solution; sonication- sonication for $3 \mathrm{~min}$. in 7:3 ethanol: water solution.

Similar results were obtained by Pearson et al. (2014). In contrast; the amount of total sand in profiles 1 (Czy, 5-25 cm) and profile 2 (Cky, 5-20 cm) decreased from sonication in a 7:3 ethanol: water solution to shaking in a 7:3 ethanol: water solution to dry sieving. The reasons for this deviation from the trend in profiles 3 and 4 is unknown but could be due to the presence of gypsum crystals occurring in the silt or fine sand-sized fractions which has not been affected by the great energy input of sonication or may be related to differences in parent materials. These results were agrees with Pearson et al. (2014). Additionally, Vieillefon (1979) mentioned that the presence of gypsum is mostly linked with fine sand fraction followed by the silt fraction.

Table 3. Total sand measured by the different disaggregation methods.

\begin{tabular}{lcccc}
\hline Profile No. & $\begin{array}{c}\text { Standard PSD } \\
\text { method } \%\end{array}$ & $\begin{array}{c}\text { Dry sieving } \\
\%\end{array}$ & $\begin{array}{c}\text { Shaking } \\
\%\end{array}$ & $\begin{array}{c}\text { Sonication } \\
\%\end{array}$ \\
\hline P 1 Czy $(5-25 \mathrm{~cm})$ & 74.4 & 95.99 & 96.0 & 96.0 \\
P 2 Cky (5-20 cm) & 84.2 & 79.26 & 80.28 & 82.0 \\
P 3 Czy $(0-25 \mathrm{~cm})$ & 72.8 & 76.91 & 76.69 & 76.62 \\
P 4 Cky $(20-80 \mathrm{~cm})$ & 89.6 & 78.5 & 78.2 & 77.8 \\
P 5 Cky $(5-35 \mathrm{~cm})$ & 84.0 & 87.3 & 86.8 & 85.5 \\
\hline
\end{tabular}

\section{Re-calculation of whole clay contents}

Clay content measured by the standard pipet method for the non-gypsum residue ranged from 6.8 to $25.2 \%$ (Table 4). The ratio of CEC/Clay is often used to evaluate dispersion errors in clay measurement, and its value commonly higher than 1 in most soils (Burt, 2011). CEC/clay ratios derived from clay contents measured by the standard method ranged from 0.07 to 1.12 . Recalculation of the clay contents to a whole soil basis (including gypsum) ranged from 2.20 to $20.47 \%$ and resulted in CEC/clay ratios ranged from 0.40 to 0.82 . In addition the clay content ranging between 2 to $50 \%$ (in gypsiferous soils) have been recorded by many researchers (e.g; Mousli, 1980; Van Alphen and de los Rios Romero, 1971; Mardoud, 1980; Dekkiche, 1976; Barzanji, 1973; Barzanji et al., 1975).

Table 4. Particle size distribution for five gypsiferous horizons by standard and modified method

\begin{tabular}{|c|c|c|c|c|c|c|c|c|c|c|c|}
\hline \multirow[t]{2}{*}{ Horizon } & \multirow{2}{*}{$\begin{array}{l}\text { Depth } \\
\text { (cm) }\end{array}$} & \multirow{2}{*}{$\begin{array}{l}\text { Gypsum } \\
\text { g kg-1 }^{-1}\end{array}$} & \multirow{2}{*}{$\begin{array}{c}\text { CEC } \\
\left.\mathrm{cmol}^{+}\right) \\
\mathrm{kg}^{-1} \\
\end{array}$} & \multicolumn{4}{|c|}{ Standard method } & \multicolumn{4}{|c|}{ Modified method } \\
\hline & & & & $\begin{array}{c}\text { Sand } \\
\%\end{array}$ & $\begin{array}{c}\text { Silt } \\
\%\end{array}$ & $\begin{array}{c}\text { Clay } \\
\%\end{array}$ & CEC/Clay & $\begin{array}{c}\text { Sand } \\
\%\end{array}$ & $\begin{array}{c}\text { Silt } \\
\%\end{array}$ & $\begin{array}{c}\text { Clay } \\
\%\end{array}$ & CEC/Clay \\
\hline \multicolumn{12}{|c|}{ Profile 1; Typic Haplogypsids } \\
\hline Czy & $5-25$ & 84.0 & 1.80 & 74.4 & 0.4 & 25.2 & 0.07 & 96.0 & 1.8 & 2.20 & 0.82 \\
\hline \multicolumn{12}{|c|}{ Profile 2; Typic Calcigypsids } \\
\hline $\begin{array}{l}\text { Cky } \\
\text { Profile } 3\end{array}$ & $\begin{array}{c}\text { 5-20 } \\
\text { Typic H }\end{array}$ & $\begin{array}{c}108 \\
\text { plogypsid }\end{array}$ & 5.20 & 84.2 & 1.4 & 14.3 & 0.36 & 82.0 & 5.24 & 12.76 & 0.41 \\
\hline Czy & $0-25$ & 82.0 & 8.25 & 72.8 & 4.4 & 22.8 & 0.36 & 76.62 & 2.91 & 20.47 & 0.40 \\
\hline \multicolumn{12}{|c|}{ Profile 4; Typic Calcigypsids } \\
\hline \multicolumn{12}{|c|}{ Profile 5; Typic Calcigypsids } \\
\hline Cky & $5-35$ & 42.0 & 3.40 & 84.0 & 8.5 & 7.5 & 0.45 & 82.5 & 10.31 & 7.19 & 0.47 \\
\hline
\end{tabular}

\section{Textural class comparison}

Texture class as determined in the field by feeling disagreed with the texture class determined from the standard particle size and modified methods for 4 of 5 samples, and that about $80 \%$ of the total samples. In 
contrast, textural class determined by the standard pipet method disagreed with class determined by modified method for $60 \%$ of the total samples tested (Table 5). The reason for this disagreement could be due to overestimation of clay content in the field. Similar results were reported by Pearson et al. (2014). Moreover, Vieillefon $(1977,1978,1979)$ in comprehensive studies on the improvement of analytical methods for gypsiferous soils, concluded that, overestimation of the clay and silt contents of gypsiferous soils occur if not corrected when done by hydrometer methods. Despite these comparisons were qualitative but they suggest that the modified method is applicable and yields particle size distribution that better reflect soil conditions observed in the field. They also suggest that the modified method shows priority in separating soil particles of the gypsiferous soils than standard pipette method.

Table 5. Comparison of textural classes obtained by feel, standard PSD method, and modified method.

\begin{tabular}{lcccc}
\hline Horizon & $\begin{array}{c}\text { Depth } \\
\text { (cm) }\end{array}$ & Field texture & Textural class & \\
\cline { 3 - 5 } & $5-25$ & SL & SCL & Modified method \\
\hline Profile 1, Czy & $5-20$ & SCL & LS & S \\
Profile 2, Cky & SCL & SCL & SL \\
Profile 3, Czy & $0-25$ & SCL & S & SL \\
Profile 4, Cky & $20-80$ & SL & LS & LS \\
Profile 5, Cky & $5-35$ & &
\end{tabular}

\section{Conclusion}

The particles of gypsiferous soils in the arid regions are mainly aggregated with Ca cations (e.g; CaCO3) and which lead to difficult in the disaggregation of particles in these types of soils. Hence, there is a need to applying alternative techniques to properly separating the particles of these unique soils. After applying developed Pearson et al. (2014) method to determine particle size distribution for selected gypsiferous soils from Al-Ahsa governorate, Saudi Arabia, the statistical analysis results revealed that the sonication for 3 minutes in a 7:3 ethanol: water solution was the most effective for sand fractions compared to dry sieving and shaking for 5 hours in 7:3 ethanol solution. The particle size distribution by the modified method showed slight increased in total sand content as compared to standard particle size method. Additionally, the textural classes obtained from the two methods were similar. Our study suggests that use of sonication for $3 \mathrm{~min}$. in a 7:3 ethanol: water solution will give accuracy in particle size measurement for gypsiferous soils. Therefore, we highly recommended using this developed method to separate sand fractions as well as to re-calculate the clay fraction for gypsiferous soils. Finally, we concluded that the determination of particle size distribution for gypsiferous soils ( $\leq 40 \%$ gypsum) using this developed method will improve the understanding and ability to proper interpret of physical behavior of these unique soils.

\section{Appendix 1.}

Field description of the studied gypsiferous soil profiles selected from Al-Ahsa governorate, Saudi Arabia.

\section{Profile 1:}

Classification (USDA): Typic Haplogypsids

Coordinates: 2536'51" N 493'ㄴ'54" E

Elevation (a.s.l): $153 \mathrm{~m}$

Slope: Nearly level
Drainage: Poorly

Vegetation: Null

Parent material: Residuum

\begin{tabular}{|c|c|c|}
\hline Horizon & Depth $(\mathrm{cm})$ & Description \\
\hline $\mathrm{C}$ & $0-5$ & $\begin{array}{l}\text { Very pale brown (10YR } 7 / 3 \text {, dry), pale brown (10YR } 6 / 3 \text {, moist), sand, single grain, non } \\
\text { sticky, non plastic; loose, few fine roots, slightly effervescence, clear, smooth boundary. }\end{array}$ \\
\hline Ckm1 & $5-25$ & $\begin{array}{l}\text { Light gray (10YR } 7 / 2 \text {, dry), light yellowish brown (2.5YR } 6 / 4 \text {, moist), sand, massive, non } \\
\text { sticky, non plastic; extremely hard, few fine roots, moderately effervescence, abrupt, smooth } \\
\text { boundary. }\end{array}$ \\
\hline Ckm2 & $25-45$ & $\begin{array}{l}\text { White (5Y } 8 / 2 \text {, dry), light olive gray ( } 5 \text { Y } 6 / 2 \text {, moist), clay, massive, very sticky, very plastic; } \\
\text { extremely hard, some weathered rock fragments, moderately effervescence, clear, smooth } \\
\text { boundary. }\end{array}$ \\
\hline $2 \mathrm{Ck} 1$ & $45-90$ & $\begin{array}{l}\text { White (5Y } 8 / 2 \text {, dry), pale yellow ( } 5 \text { Y } 7 / 3 \text {, moist), very gravely clay, very sticky, very plastic; } \\
\text { extremely hard, some weathered rock fragments, moderately effervescence, diffuse, smooth } \\
\text { boundary. }\end{array}$ \\
\hline $2 \mathrm{Ck} 2$ & $90-120$ & $\begin{array}{l}\text { White ( } 5 \text { Y } 8 / 2 \text {, dry), pale yellow ( } 5 \text { Y } 7 / 3 \text {, moist), gravely clay, massive, very sticky, very } \\
\text { plastic; extremely hard, some weathered rock fragments, moderately effervescence, clear, } \\
\text { smooth boundary. }\end{array}$ \\
\hline $3 \mathrm{Cm}$ & $120+$ & $\begin{array}{l}\text { Light gray ( } 5 Y \text { } 7 / 2 \text {, dry), light gray ( } 2.5 \mathrm{Y} 7 / 2 \text {, moist), sandy loam, massive, sticky, plastic; } \\
\text { extremely hard, slightly effervescence, abrupt, smooth boundary. }\end{array}$ \\
\hline
\end{tabular}




\section{Profile 2:}

Classification (USDA): Typic Calcigypsids

Coordinates: 2530'32" N 4935'37" E

Parent material: Transported sand mixed with colluvial materials derived from sandstone and limestone

Elevation (a.s.l): $153 \mathrm{~m}$

Slope: Nearly level

Drainage: Imperfectly drained

Vegetation: Few scattered natural vegetation (Haloxylon licornicum)

\begin{tabular}{ccl}
\hline Horizon & Depth (cm) & \multicolumn{1}{c}{ Description } \\
\hline Cz1 & $0-5$ & $\begin{array}{l}\text { Light yellowish brown (10YR 6/4, dry), brown (10YR 5/3, moist), loamy sand, slightly } \\
\text { sticky, non plastic; soft, common fine cracks, slightly effervescence, clear, smooth boundary. }\end{array}$ \\
Ckz2 & $5-20$ & $\begin{array}{l}\text { Very pale brown (10YR 7/3, dry), brown (10YR 5/3, moist), sandy loam, massive, slightly } \\
\text { sticky, slightly plastic; soft, very fine roots, slightly effervescence, abrupt, smooth boundary. } \\
\text { Very pale brown (10YR 7/3, dry), yellowish brown (10YR 5/4, moist), sand, massive, non } \\
\text { sticky, non plastic; slightly hard, few fine decomposed organic matter, slightly effervescence, } \\
\text { abrupt, smooth boundary }\end{array}$ \\
C4 & 20-40 & $\begin{array}{l}\text { Very pale brown (10YR 7/4, dry), light yellowish brown (10Y 6/4, moist), sandy loam, } \\
\text { slightly sticky, slightly plastic; slightly effervescence, clear, wavy boundary. } \\
\text { Light gray (10Y 7/2, dry), pale brown (10Y 6/3, moist), sandy loam, slightly sticky, slightly } \\
\text { plastic; few fine distinct sharp mottles, moderately effervescence, clear, smooth boundary. }\end{array}$ \\
C5 & $70-105$ &
\end{tabular}

\section{Profile 3:}

Classification (USDA): Typic Haplogypsids

Coordinates: 2517'00" N 4943'16" E

Parent material: Alluvium

Elevation (a.s.l): $150 \mathrm{~m}$

Slope: Nearly level

Drainage: Well drained

Vegetation: Old farm cultivated with date palm and pomegranate trees.

\begin{tabular}{|c|c|c|}
\hline Horizon & Depth (cm) & Description \\
\hline $\mathrm{Ap}$ & $0-25$ & $\begin{array}{l}\text { Grayish brown (10YR } 5 / 2 \text {, dry), very dark grayish brown (10YR } 3 / 2 \text {, moist), sandy clay } \\
\text { loam, weak fine subangular blocky, sticky, plastic; loose, very few fine lime spots, common } \\
\text { fine and medium roots, clear, smooth boundary. }\end{array}$ \\
\hline Czy & $25-45$ & $\begin{array}{l}\text { Light gray (10YR } 7 / 2 \text {, dry) and light yellowish brown }(2.5 \text { YR } 6 / 4 \text {, moist), sand, massive, non } \\
\text { sticky, non plastic; extremely hard, few fine roots, abrupt, smooth boundary. }\end{array}$ \\
\hline C & $45-80$ & $\begin{array}{l}\text { Light brownish gray (10YR } 6 / 2 \text {, dry), dark grayish brown (10YR } 4 / 2 \text {, moist), sand, massive, } \\
\text { non sticky, non plastic; hard, some hard fine lime spots, clear, smooth boundary. }\end{array}$ \\
\hline $\mathrm{Ck}$ & $80-120$ & $\begin{array}{l}\text { Light gray (10YR } 7 / 2 \text {, dry), grayish brown (10YR } 5 / 2 \text {, moist), loamy sand, massive, slightly } \\
\text { sticky, non plastic; very hard, common fine soft lime segregation, clear, smooth boundary. }\end{array}$ \\
\hline $2 \mathrm{C}$ & $120-185$ & $\begin{array}{l}\text { Light olive brown ( } 2.55 \mathrm{Y} 5 / 2 \text {, dry), dark grayish brown (10YR } 4 / 2 \text {, moist), loamy sand, } \\
\text { massive, slightly sticky, non plastic; hard, clear, smooth boundary. }\end{array}$ \\
\hline
\end{tabular}

\section{Profile 4:}

Classification (USDA): Typic Calcigypsids

Coordinates: 2517'00" N 494'ㄹ' 12 " E

Parent material: Alluvium

Elevation (a.s.l): $113 \mathrm{~m}$

Slope: Flat

Drainage: Well drained

Vegetation: Cultivated area with palm trees

\begin{tabular}{|c|c|c|}
\hline Horizon & Depth $(\mathrm{cm})$ & Description \\
\hline Ap1 & $0-20$ & $\begin{array}{l}\text { Pale brown (10YR } 6 / 3 \text {, dry), very dark grayish brown (10YR 3/2, moist), sandy loam, } \\
\text { massive, non sticky, non plastic; soft, abrupt smooth boundary. }\end{array}$ \\
\hline Cky & $20-80$ & $\begin{array}{l}\text { Grayish brown (10YR } 5 / 3 \text {, dry), very dark gray (10YR } 3 / 1 \text {, moist), sand, single grain, non } \\
\text { sticky, non plastic; loose, abrupt, smooth boundary. }\end{array}$ \\
\hline C1 & $80-110$ & $\begin{array}{l}\text { Pale brown (10YR } 6 / 3 \text {, dry), dark grayish brown (10YR 4/2, moist), sandy loam, massive, } \\
\text { slightly sticky, slightly plastic; soft, abrupt smooth boundary. }\end{array}$ \\
\hline C2 & $110-140$ & $\begin{array}{l}\text { Very pale brown ( } 10 \text { YR } 8 / 3 \text {, dry), yellowish brown (10YR } 5 / 4 \text {, moist), sand, single grain, } \\
\text { slightly sticky, slightly plastic; loose, diffuse, smooth boundary. }\end{array}$ \\
\hline
\end{tabular}




\section{Profile 5:}

Classification (USDA): Typic Calcigypsids

Coordinates: 2531'30" N 4935'52" E

Parent material: Lacustrine

Elevation (a.s.l): $132 \mathrm{~m}$

Slope: Flat

Drainage: Moderately well drained

Vegetation: Common scattered natural vegetation (Phragmites australis)

\begin{tabular}{|c|c|c|}
\hline Horizon & Depth $(\mathrm{cm})$ & Description \\
\hline $\mathrm{Az}$ & $0-5$ & $\begin{array}{l}\text { Very pale brown (10YR 7/3, dry) and pale brown (10YR 6/3, moist), sand, single grain, non } \\
\text { sticky, non plastic; loose, few fine roots, slightly effervescence, clear, smooth boundary. }\end{array}$ \\
\hline Cky1 & $5-35$ & $\begin{array}{l}\text { Light gray ( } 2.5 \mathrm{Y} 7 / 2 \text {, dry), light brown (10YR } 6 / 3 \text {, moist), sandy loam, weak fine subangular } \\
\text { blocky, slightly sticky, slightly plastic; soft, few gravels, abrupt, smooth boundary. }\end{array}$ \\
\hline 2Ck2 & $35-55$ & $\begin{array}{l}\text { Very pale brown (10YR } 8 / 3 \text {, dry), very pale brown (10YR } 7 / 3 \text {, moist), clay, weak fine } \\
\text { subangular blocky, very sticky, very plastic; soft, few fine mottles, clear, smooth boundary. }\end{array}$ \\
\hline 2Ck3 & 55-90 & $\begin{array}{l}\text { Light brownish gray (10YR } 6 / 2 \text {, dry), dark gray ( } 10 \text { YR } 4 / 1 \text {, moist), sandy clay, very sticky, } \\
\text { very plastic; slightly hard, clear, smooth boundary. }\end{array}$ \\
\hline 2Ckm & $90-130$ & $\begin{array}{l}\text { White (10YR } 8 / 2 \text {, dry), very pale brown (10YR } 7 / 3 \text {, moist), clay, massive, very sticky, very } \\
\text { plastic; extremely hard, few narrow channels, few fine soft lime spots, clear, smooth } \\
\text { boundary. }\end{array}$ \\
\hline
\end{tabular}

\section{Acknowledgements}

The authors are indebted their greatly thank to Technical Assistant Khalid El-Enazi, Laboratory of Remote Sensing and GIS, College of Food and Agriculture Sciences, King Saud University for his help.

\section{References}

Al-Barrak, K., Rowell, D.L., 2006. The solubility of gypsum in calcareous soils. Geoderma 136 (3-4): 830-837.

Artieda, O., 1996. Génesis y distribución de suelos en un medio semiárido. Quinto de Ebro (Zaragoza). Ministerio de Agricultura, Pesca y Alimentación (MAPA). pp 222.

Aznar, J. M., Poch, R. M., Badía, D., 2013. Soil catena along gypseous woodland in the middle Ebro Basin: soil properties and micromorphology relationships. Spanish Journal of Soil Science 3(1): 28-44.

Horváth, B., Opara-Nadi, O., Beese, F., 2005. A simple method for measuring the carbonate content of soils. Soil Science Society America Journal 69(4): 1066-1068.

Barzanji, A. F., 1973. Gypsiferous soils of Iraq. Ph.D. Thesis, University of Ghent, Belgium.

Barzanji, A. F., Sys, C., Eswaran, H., 1975. The clay mineralogy of gypsiferous soils of Iraq. Proceedings of the International Clay Conference, Mexico City, 1975: 1(r23. (Ed. S.W. Bailey). Applied Publishing Ltd. Wilmette, Illinois, USA.

Burt, R., 2011. Soil survey laboratory information manual. Soil Survey Investigations Report No. 45, Version 2.0 United State Department of Agriculture-Natural Resources Conservation Service, National Soil Survey Center, Lincoln, Nebraska, USA. 506p.

Cantón, Y., Solé-Benet, A., Lázaro, R., 2003. Soil-geomorphology relations in gypsiferous materials of the Tabernas Desert (Almería, SE Spain). Geoderma 115(3-4):193-222.

Grossman, R.B., Reinsch, T.G., 2002. Bulk Density and Linear Extensibility. In: Methods of Soil Analysis: Part 4 Physical Methods, (Dane, J.H., Topp, C.G. (Eds). Soil Science Society of America Book Series, Madison, Wisconsin, USA. pp. 201-228

Dekkiche, B., 1976. Sur quelques sols à accumulation de gypse dans le Hodna. Annales de I'Institut National Agronomique 6.

FAO, 1990. Management of gypsiferous soils. FAO Soil Bulltein 62. Food and Agricultural Organization of United Nations, Rome. Italy.

FAO, 2006. Guideline for Soil Profile Description. Food and Agricultural Organization of United Nation. Rome, Italy.

Florea, N., Al-Joumaa, Kh., 1998. Genesis and classification of gypsiferous soils of the Middle Euphrates Floodplain, Syria. Geoderma 87(1-2): 67-85.

Fuller, L., Goh, T.B., 1992. Stability-energy relationships and their application to aggregation studies. Canadian Journal of Soil Science 72(4), 453-466.

Gee, G. W., Bauder, J. W., 1994. Particle-size analysis. In: Methods of Soil Analysis, Part 1, Physical and Mineralogical Methods. Klute, A. (Ed.) American Society of Agronomy and Soil Science Society of America, Madison, Wisconsin. USA. pp.383-411. 
IBM Corp, 2012. Statistics for Windows (Computer Program Manual), IBM SPSS Armonk, NY, USA.

Imeson, A., Vis, M., 1984. Assessing soil aggregate stability by water-drop impact and ultrasonic dispersion. Geoderma 34: 185-200.

Mardoud, T., 1980. Gypsiferous soils in the Balikh basin - characteristics and productivity. Soil Taxonomy Workshop, ACSAD:30B-320.

Soil Atlas, 1985. General Soil Map of the Kingdom of Saudi Arabia. Kingdom of Saudi Arabia, Ministry of Agriculture and Water, Land Management Department, 292p.

Mousli, O.F., 1980. Methods of evaluation and classification of gypsiferous soils and suitability for irrigated agriculture. In: Proceedings of the 3rd International Soil Classification Workshop. Beinroth, F.H., Osman, A.(Eds.). Arab Centre for the Study of Arid and Dry Lands (ACSAD). Damascus, Syria. pp.278-307.

Oades, J.M, Waters, A.G., 1991. Aggregate hierarchy in soils. Australian Journal of Soil Research 29(6): 815 - 828.

Pearson, J.M., Monteith, E.S., Ferguson, R. R., Hallmark, T.C., Hudnall, H.W., Monger, C.H., Reinsch, G.T., West, T.L. 2014. A method to determine particle size distribution in soils with gypsum. Geoderma 237-238: 318-324.

Vincent, P., 2008. Saudi Arabia: An Environmental Overview. Taylor \& Francis Pubications. London, UK. 332p.

Poch, R.M., Artieda, O., Herrero, J., Lebedeva-Verba, M., 2010. Gypsic features. In: Interpretation of Micromorphological Features of Soils and Regoliths. Stoops, G., Marcelino, V., Mees, F. (Eds.). Elsevier, Amsterdam, The Netherlands, pp. 195-216.

Porta, J., 1998. Methodologies for the analysis and characterization of gypsum in soils: a review. Geoderma 87(1-2): 3146.

Soil Survey Staff, 2014a. Keys to Soil Taxonomy, 12th edition. United States Department of Agriculture, Natural Resources Conservation Service, USA. 359p

Soil Survey Staff, 2014b. Kellogg soil survey laboratory methods manual. Soil Survey Investigations Report No. 42, Version 5.0. United States Department of Agriculture, Natural Resources Conservation Service, USA. 1001p.

Sparks, D.L., Page, A.L., Helmke, P.A., Loeppert, R.H., 1996. Methods of Soil Analysis Part 3-Chemical Methods. SSSA Book Series 5.3. Soil Science Society of America, American Society of Agronomy, Madison, WI, USA. 1390p.

Van-Alphen, J.G., de los Ríos Romero, F. 1971. Gypsiferous Soils. Notes on their characteristics and management. Bulletin No. 12. International Institute of Land Reclamation and Improvement, Wageningen, The Netherlands.

Vieillefon, J., 1978. Etude de l'application des phénomènes de déshydration et de réhydration du sulfate de calcium à 1 'estimation des teneurs en eau et en gypse des sols gypseux. ORSTOM, Division des Sols, Tunisie, ES 146 DRES.

Vieillefon, J., 1977. Recherches sur l'analyse granulométrique des sols gypseux. Ministère de l'Agriculture, Direction des Resources en Eaux et en Sols (DRES) et ORSTOM, Tunisie, ES 137 DRES.

Vieillefon, J., 1979. Contribution to the improvement of analysis of gypsiferous soils. Cahiers/ORSTOM, Serie Pédologie 17:195-223. 